\title{
Simulation of Water and Salt Dynamics in the Soil Profile in the Semi-Arid Region of Tunisia-Evaluation of the Irrigation Method for a Tomato Crop
}

\author{
Sabri Kanzari ${ }^{1, *(\mathbb{D} \text {, Issam Daghari }}{ }^{2}$, Jiři Šimůnek ${ }^{3, *(0)}$, Anis Younes ${ }^{4}\left(\mathbb{D}\right.$, Riadh Ilahy ${ }^{5}$, \\ Sana Ben Mariem ${ }^{1}$, Mourad Rezig ${ }^{1}$, Béchir Ben Nouna ${ }^{1}$, Hassouna Bahrouni ${ }^{1}$ and \\ Mohamed Ali Ben Abdallah ${ }^{1}$ \\ 1 INRGREF, Laboratory of Rural Engineering, University of Carthage, Ariana 2080, Tunisia; \\ benmeriem.sana@gmail.com (S.B.M.); rezigue_mourad@yahoo.fr(M.R.); b_bechir1106@yahoo.com (B.B.N.); \\ h.bahrouni@gmail.com (H.B.); benabdallah_medali@yahoo.fr (M.A.B.A.) \\ 2 INAT, Tunis 1082, Tunisia; issam.daghari@gmail.com \\ 3 Department of Environmental Sciences, University of California Riverside, Riverside, CA 92521, USA \\ 4 LHyGES, Universite de Strasbourg/EOST/ENGEES, CNRS, 67084 Strasbourg, France; younes@unistra.fr \\ 5 INRAT, Laboratory of Horticulture, University of Carthage, Ariana 2080, Tunisia; bn.riadh@gmail.com \\ * Correspondence: sabri.kanzari@gmail.com (S.K.); jiri.simunek@ucr.edu (J.Š.); Tel.: +1-951-827-7854 (J.Š.)
}

Received: 4 May 2020; Accepted: 28 May 2020; Published: 3 June 2020

\begin{abstract}
In Tunisia, water used for irrigation is often saline, increasing the risk of salinization for soils and crops. In this study, an experiment was conducted on a tomato crop cultivated on a silty-clay soil irrigated with three different water qualities: 0, 3.5, and $7 \mathrm{dS} \cdot \mathrm{m}^{-1}$. Experimental data were then used to calibrate and validate the Hydrus-1D model, which simulates water flow and salt transfer in soils. The successfully-calibrated and validated model was then used to study the combined effects of the soil osmotic and soil matrix potentials on root water uptake. The values of the root mean square error (RMSE), the coefficient of determination $(C D)$, the modeling efficiency $(E F)$, and the coefficient of residual mass (CRM) were close to their optimal values for both soil water content and soil electrical conductivity profiles, indicating the reliability of the model to reproduce water and salt dynamics. Relative yields $\left(Y_{r}\right)$, indirectly estimated using actual and potential root water uptake (transpiration), indicated that the multiplicative stress response model (using the S-shape model) satisfactorily simulates measured yields and reproduces the effects of irrigation with saline waters on crop yields. An alternative scenario using a reduction of water requirements by $50 \%$ was investigated to assess an irrigation method with considerable water savings. As the results show that relative yields, $Y_{r}$, were only slightly reduced, the crop water requirements estimated by CROPWAT 8.0 must have been overestimated. The variation of the soil salinity in the root zone highlighted a high salinization risk in the short-term when water of $7 \mathrm{dS} \cdot \mathrm{m}^{-1}$ is used for irrigation.
\end{abstract}

Keywords: soil salinity; saline water; unsaturated soil; root water uptake; Hydrus-1D; Tunisia

\section{Introduction}

In arid and semi-arid countries such as Tunisia, the use of marginal waters such as saline waters or treated wastewater is a necessity. However, the use of these waters carries a long-term risk for soils, groundwater, and crops [1-3]. Irrigation with saline waters generally results in salinization of the topsoil [4-6], and, in the long term, salts leaching under the effects of rainfall can contaminate groundwater $[7,8]$. On the other hand, multiple authors have shown that the salinization phenomenon in the topsoil can be cyclic, and the effect of salinity on crops can be attenuated with proper management 
that involves appropriate irrigation for salt leaching [9-11]. However, in arid regions, reduction in agricultural water use is part of the water resource management policy. This, requires lower irrigation doses and involves irrigation strategies such as deficit irrigation and partial root-zone drying. If one of these techniques is associated with the use of brackish water, the risk of salinization can become dramatic, especially for a strategic crop like tomatoes (in Tunisia).

Numerical models are important and useful tools for assessing the risk of soil salinization and its adverse effects on crop yields. The Hydrus-1D model [12], widely used for this purpose, simulates the movement of water and solutes by numerically solving the Richards and advection-dispersion equations, respectively. The model also considers the simultaneous effects of the soil osmotic and matrix potentials on root water uptake. The model does not directly simulate crop yield but calculates a relative yield as a ratio of actual and potential root water uptake (transpiration) [13]. Several authors have applied the Hydrus-1D model to study water and salt dynamics in agricultural soils and their effects on crops in semi-arid regions, as well as developed management scenarios and long-term forecasts using this model (e.g., $[14,15])$.

In this context, the objectives of this study are (a) to calibrate and validate the Hydrus-1D model for simulating water and salt dynamics in a soil cultivated with a tomato crop irrigated with saline waters and (b) to estimate crop water requirements using this calibrated and validated model.

\section{Materials and Methods}

\subsection{Field Experiment and Irrigation Management}

The field experiment was carried out in the city of Ariana ( $\left.36^{\circ} 50^{\prime} 40.791^{\prime \prime} \mathrm{N}, 10^{\circ} 11^{\prime} 13.795^{\prime \prime} \mathrm{E}\right)$ in Tunisia, a semi-arid Mediterranean region. The Ariana region has a semi-arid Mediterranean climate with mild, wet winters and dry and hot summers. The average annual temperature is $18.7^{\circ} \mathrm{C}$, with the winter minimum of $6{ }^{\circ} \mathrm{C}$ and the summer maximum exceeding $45^{\circ} \mathrm{C}$. The annual average rainfall is $450 \mathrm{~mm}$, and the average annual reference evapotranspiration is $1100 \mathrm{~mm}$. The soil at the site is a Fluvisol with a loamy-clay texture. The groundwater level is beneath $8 \mathrm{~m}$. A tomato crop (Rio Grande) (Petoseed Saticoy, California, USA) was cultivated with a planting density of 1750 plants/ha. The crop was planted on 17 April 2017 and harvested on 3 August 2017.

Tomato water requirements were estimated from 10-year climate data (2007-2017). Mean values of meteorological variables were used to estimate reference evapotranspiration using the Penman-Monteith equation [16]. The crop coefficient $\left(K_{c}\right)$ for three crop stages were taken from [16] to calculate actual evapotranspiration. For the initial stage $K_{c}=0.6$, for the medium stage $K_{c}=1.15$, and for the final stage $K_{c}=0.8$. CROPWAT 8.0 software (FAO, Rome, Italy) [17] was used to establish irrigation scheduling. CROPWAT 8.0 estimated water requirements of the tomato crop to be $720 \mathrm{~mm}$. Surface irrigation was used to deliver water to plants (30 plants for each treatment) in three qualities:

- Freshwater (FW) with a salinity of $0 \mathrm{dS} \cdot \mathrm{m}^{-1}$;

- Saline water with a salinity of $3.5 \mathrm{dS} \cdot \mathrm{m}^{-1}$;

- Highly saline water with a salinity of $7 \mathrm{dS} \cdot \mathrm{m}^{-1}$.

\subsection{The Hydrus-1D Model}

\subsubsection{Model Inputs}

\section{Soil Hydraulic Properties}

The soil hydraulic properties were measured at the Laboratory of Rural Engineering (INRGREF, Ariana, Tunisia) using soil samples collected in March 2017 at depths of 20, 40, 60, and $80 \mathrm{~cm}$, with three replicates for each depth. The pressure plate apparatus [18] was used to measure the volumetric water content at multiple pressure heads for each soil sample. The collected experimental data were fitted to the van Genuchten retention model [19] using the RETC software (U.S. Department of Agriculture, 
Riverside, USA) [20] to estimate the residual water content $\theta_{r}$, the saturated water content $\theta_{s}$, and the two shape parameters $\alpha$ and $n$. Saturated hydraulic conductivity $\left(K_{s}\right)$ was determined by a falling head permeameter method. The values of these parameters for different soil depths are given in Table 1.

Table 1. Soil hydraulic parameters [19] for different soil depths.

\begin{tabular}{|c|c|c|c|c|c|}
\hline Depth (cm) & $\theta_{r}\left(\mathrm{~cm}^{3} \cdot \mathrm{cm}^{-3}\right)$ & $\theta_{s}\left(\mathrm{~cm}^{3} \cdot \mathrm{cm}^{-3}\right)$ & $\alpha\left(\mathrm{cm}^{-1}\right)$ & $n$ & $K_{s}\left(\mathrm{~cm} \cdot \mathrm{d}^{-1}\right)$ \\
\hline $0-20$ & 0.01 & 0.50 & 0.012 & 1.23 & 12.60 \\
\hline $20-40$ & 0.09 & 0.48 & 0.015 & 1.32 & 8.90 \\
\hline $40-60$ & 0.09 & 0.50 & 0.010 & 1.42 & 12.60 \\
\hline $60-80$ & 0.09 & 0.47 & 0.012 & 1.39 & 12.50 \\
\hline
\end{tabular}

\section{Solute Transport Parameters}

Soil dispersivity $\lambda(\mathrm{cm})$ was estimated using laboratory experiments on undisturbed soil columns [21]. The distribution coefficient $K_{d}$ for total dissolved solutes was measured using batch experiments [22]. The bulk density $(B D)$ was measured for each soil layer using the cylinder method. The measured solute transport parameters for different depths are summarized in Table 2.

Table 2. Solute transport parameters for different soil depths.

\begin{tabular}{cccc}
\hline Depth $(\mathbf{c m})$ & $\boldsymbol{B D}\left(\mathbf{g} \cdot \mathbf{c m}^{-\mathbf{3}}\right)$ & $\boldsymbol{\lambda}(\mathbf{c m})$ & $\boldsymbol{K}_{\boldsymbol{d}}\left(\mathbf{c m}^{\mathbf{3}} \cdot \mathbf{g}^{-\mathbf{1}}\right)$ \\
\hline $0-20$ & 1.43 & 5.80 & 0.14 \\
$20-40$ & 1.46 & 5.40 & 0.20 \\
$40-60$ & 1.39 & 4.60 & 0.30 \\
$60-80$ & 1.51 & 2.80 & 0.35 \\
\hline
\end{tabular}

\section{Crop Measurements and Models}

The plant height, rooting depth, and the leaf area index (LAI) were measured every ten days from the planting date to the harvest date with three replicates for each parameter (Table 3). The LAI was estimated by the analysis of the scanned leaves (5 to 10) images using Mesurim Pro [23]. The measured values of the relative crop yield were determined by a direct weighting using an accurate digital balance.

Table 3. Tomato crop parameters for each water quality scenario.

\begin{tabular}{|c|c|c|c|c|c|c|c|c|}
\hline \multirow[b]{2}{*}{ Water Quality } & \multirow[b]{2}{*}{ Parameter } & \multicolumn{7}{|c|}{ Day after Planting } \\
\hline & & 10 & 20 & 30 & 40 & 50 & 60 & 70 \\
\hline \multirow{3}{*}{ Freshwater } & Crop Height (cm) & 5 & 6 & 9 & 14 & 33 & 35 & 38 \\
\hline & LAI & 0.35 & 1 & 2 & 2.5 & 2.75 & 2.8 & 2.85 \\
\hline & Root Depth (cm) & 5 & 10 & 15 & 20 & 25 & 30 & 35 \\
\hline \multirow{3}{*}{$3.5 \mathrm{dS} \cdot \mathrm{m}^{-1}$} & Crop Height (cm) & 4.5 & 5.5 & 8 & 10 & 18 & 22 & 25 \\
\hline & LAI & 0.35 & 0.98 & 1.98 & 2.25 & 2.2 & 2.2 & 2.2 \\
\hline & Root Depth (cm) & 4 & 8 & 12 & 16 & 20 & 24 & 28 \\
\hline \multirow{3}{*}{$7 \mathrm{dS} \cdot \mathrm{m}^{-1}$} & Crop Height (cm) & 4 & 6 & 10 & 11 & 13 & 15 & 19 \\
\hline & LAI & 0.35 & 0.96 & 1.96 & 2.2 & 1.8 & 1.5 & 1.5 \\
\hline & Root Depth (cm) & 4 & 7 & 11 & 14 & 18 & 21 & 25 \\
\hline
\end{tabular}

The S-shape [24] and threshold and slope models [25] were used to simulate the effect of the soil matrix and osmotic potentials on root water uptake, respectively. It was considered that the effects of saturation and salinity were multiplicative. The threshold and slope parameters were $4.59 \mathrm{dS} \cdot \mathrm{m}^{-1}$ and $5 \%$, respectively, as suggested by [25], and the two parameters of the S-shape model were $P_{50}=-800 \mathrm{~cm}$ and $P_{3}=3$. 


\subsubsection{Calibration and Validation}

Soil sampling was carried out on the first day (initial) of the experiment, and then after 30, 50, 70 , and 109 days (final) at depths of 20,40,60, and $80 \mathrm{~cm}$. Soil water content and salt content were measured using the gravimetric method and the saturated paste extract, respectively.

Hydrus-1D calibration was performed for the experiment carried out with fresh water. The two parameters $\alpha$ and $n$ were slightly adjusted during the water movement calibration process and $K_{d}$ during the solute transport calibration process; all three parameters were calibrated for the two soil layers of $20-40 \mathrm{~cm}$ and $40-60 \mathrm{~cm}$. The simulation duration was 109 days, and the output dates corresponded with sampling days. Irrigation/rainfall and evapotranspiration were used to define the atmospheric boundary condition for the soil surface (Figure 1), and a free drainage boundary condition was used at the bottom boundary. Only two rainfall events were recorded on days 49 and 50, with a total amount of $40 \mathrm{~mm}$. The concentration flux boundary condition was used at both boundaries for solute transport. Hydrus-1D validation was performed using the two other experiments with saline waters. The same parameters obtained by calibration for experiments with freshwater were used as input during validation, except for the irrigation water quality.

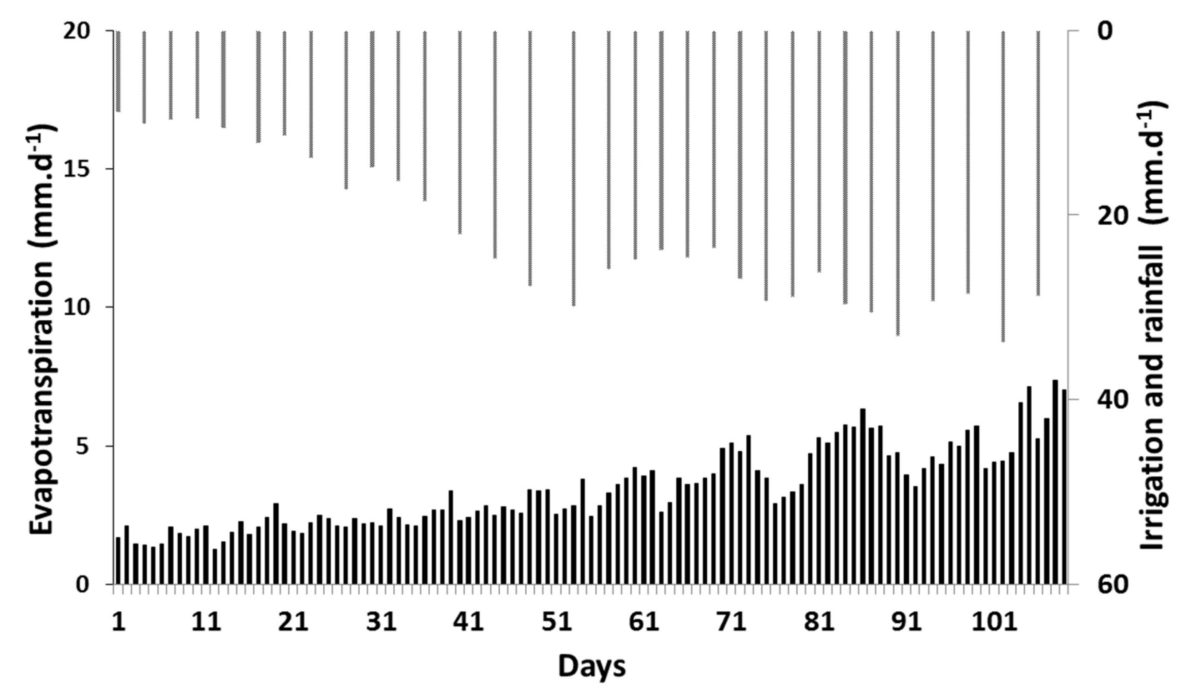

Figure 1. Daily evapotranspiration, rainfall, and irrigation during the experiments.

\subsubsection{Statistical Evaluation}

The Hydrus-1D results were evaluated graphically by plotting measured and simulated soil water content and soil salinity as a function of soil depth and statistically by calculating the root mean square error (RMSE), the coefficient of determination $(C D)$, the modeling efficiency $(E F)$, and the coefficient of residual mass (CRM) [26]. RMSE values show how much the simulations under- or overestimated the measurements. $C D$ represents the ratio between the scatter of simulated values to the average measured value. The $E F$ value compares simulated values to the average measured value. A negative $E F$ value indicates that the average measured value gives a better estimate than simulated values. $C R M$ is a measure of the tendency of the model to overestimate or underestimate measurements. Positive CRM values indicate that the model underestimates measurements, and negative CRM values indicate a tendency to overestimate measurements. For a perfect fit between observed and simulated data, values of RMSE, $C D, E F$, and $C R M$ should equal $0,1,1$, and 0 , respectively. 


$$
\begin{gathered}
\operatorname{RMSE}(\%)=\frac{\sqrt{\frac{\sum_{i=1}^{n}\left(s_{i}-m_{i}\right)^{2}}{n}}}{\bar{m}} \times 100 \\
C D=\frac{\sum_{i=1}^{n}\left(m_{i}-\bar{m}\right)^{2}}{\sum_{i=1}^{n}\left(s_{i}-\bar{m}\right)^{2}} \\
E F=1-\frac{\sum_{i=1}^{n}\left(s_{i}-m_{i}\right)^{2}}{\sum_{i=1}^{n}\left(m_{i}-\bar{m}\right)^{2}} \\
C R M=\frac{\sum_{i=1}^{n}\left(s_{i}-m_{i}\right)}{n \cdot \bar{m}}
\end{gathered}
$$

where $s_{i}$ are simulated values, $m_{i}$ are measured values, $\bar{m}$ is the average value of observed data, and $n$ is the number of observations.

\section{Results}

\subsection{Water and Salts Movement}

Figures 2 and 3 show variations in soil water content and salts profile, respectively, for the three treatments with fresh and saline waters. The soil water content profiles show that:

- Soil water contents increased with time in all soil horizons compared to the initial soil water contents due to irrigation events.

- The soil water content in the soil surface layer $(0-40 \mathrm{~cm})$ reached its maximum value after 50 days, and then it gradually decreased. In the treatments with saline water, the soil water content reached higher values, especially in the $20-40 \mathrm{~cm}$ layer.

- Variations in the soil water content are lower in the lower part of the soil profile $(40-80 \mathrm{~cm})$. Soil water contents reached $0.45 \mathrm{~m}^{3} \cdot \mathrm{m}^{-3}$ in the three treatments.

The soil salts profiles measured in the three treatments show that:

- $\quad$ The salts were continuously leached from the soil profile irrigated with fresh water. Desalination was more important in the surface layer than in deeper layers.

- The opposite phenomenon was observed in the other two treatments with saline waters, i.e., continuous accumulation of salts in the soil profile. Soil salinity reached $6.7 \mathrm{dS} \cdot \mathrm{m}^{-1}$ at the soil surface and $4.6 \mathrm{dS} \cdot \mathrm{m}^{-1}$ deeper in the soil profile of the treatment with irrigation water quality of $3.5 \mathrm{dS} \cdot \mathrm{m}^{1}$. Maximum salinity values of $11 \mathrm{dS} \cdot \mathrm{m}^{-1}$ and $6 \mathrm{dS} \cdot \mathrm{m}^{-1}$ were, respectively, measured at the soil surface and the bottom of the soil profile in the treatment with irrigation water quality of $7 \mathrm{dS} \cdot \mathrm{m}^{-1}$. 

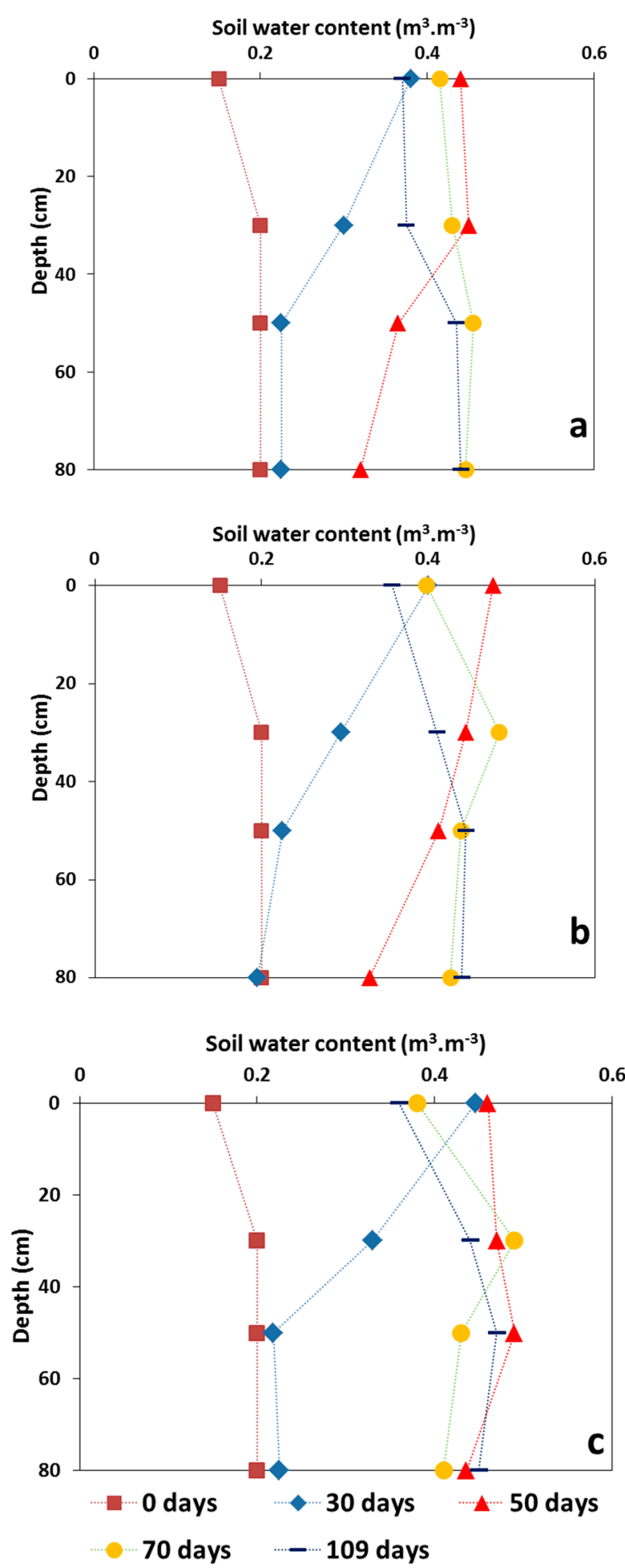

Figure 2. Measured soil water content profiles for treatments with (a) fresh, (b) saline $\left(3.5 \mathrm{dS} \cdot \mathrm{m}^{-1}\right)$, and (c) saline (7 dS.m $\left.\mathrm{m}^{-1}\right)$ water at 0,30 50, 70, and 109 days. 

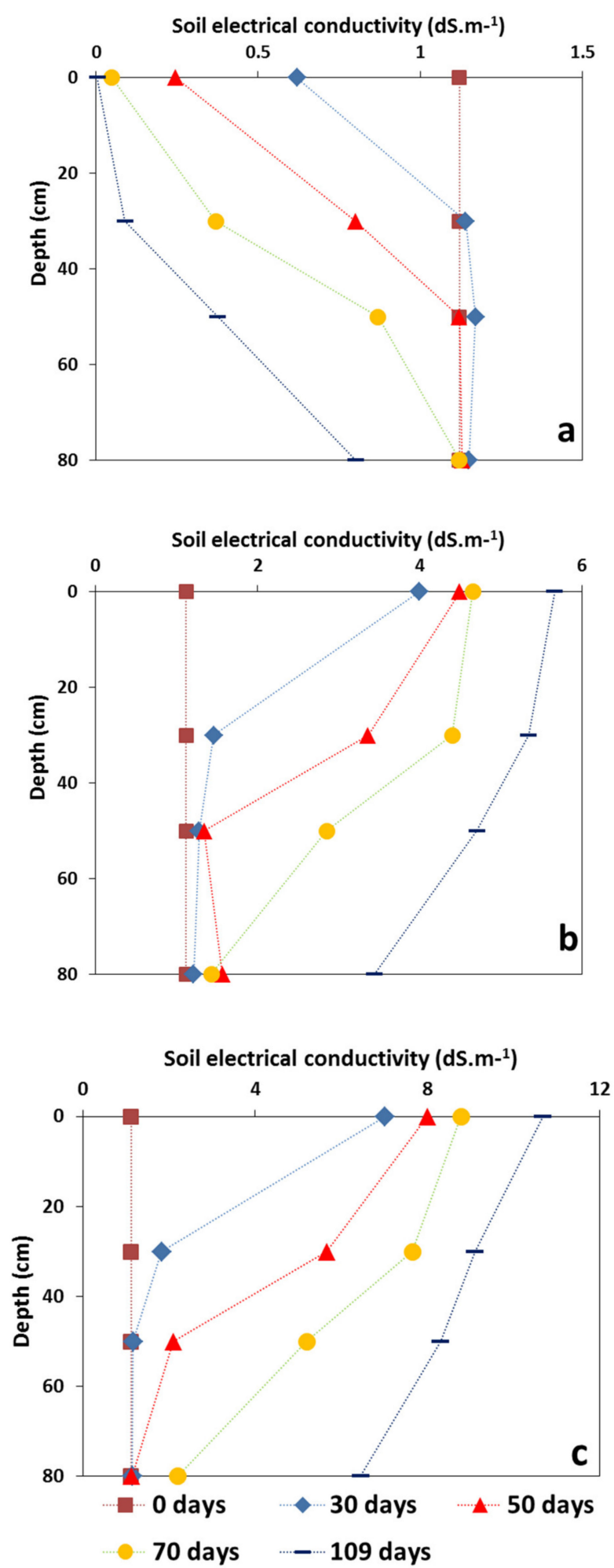

Figure 3. Measured soil salts profiles for treatments with (a) fresh, (b) saline $\left(3.5 \mathrm{dS} \cdot \mathrm{m}^{-1}\right)$, and (c) saline $\left(7 \mathrm{dS} \cdot \mathrm{m}^{-1}\right)$ water at 0,30 50, 70, and 109 days. Different scales are used on the horizontal axis.

\subsection{Hydrus-1D Calibration and Validation}

\subsubsection{Soil Water Profiles}

The measured and simulated soil water profiles for the treatment irrigated with freshwater are plotted in Figure 4. The simulated soil water content values are close to the measured values. 
The Hydrus-1D model tends to slightly underestimate measured water contents, with RMSE (\%) values (for the whole profile) of 5.4, 5.3, 2.6, and 4.9\%, at 30,50, 70, and 109 days, respectively. The CD, EF, and CRM indicators are close to their optimal values and demonstrate a good agreement between simulated (using calibrated parameters) and observed water contents.

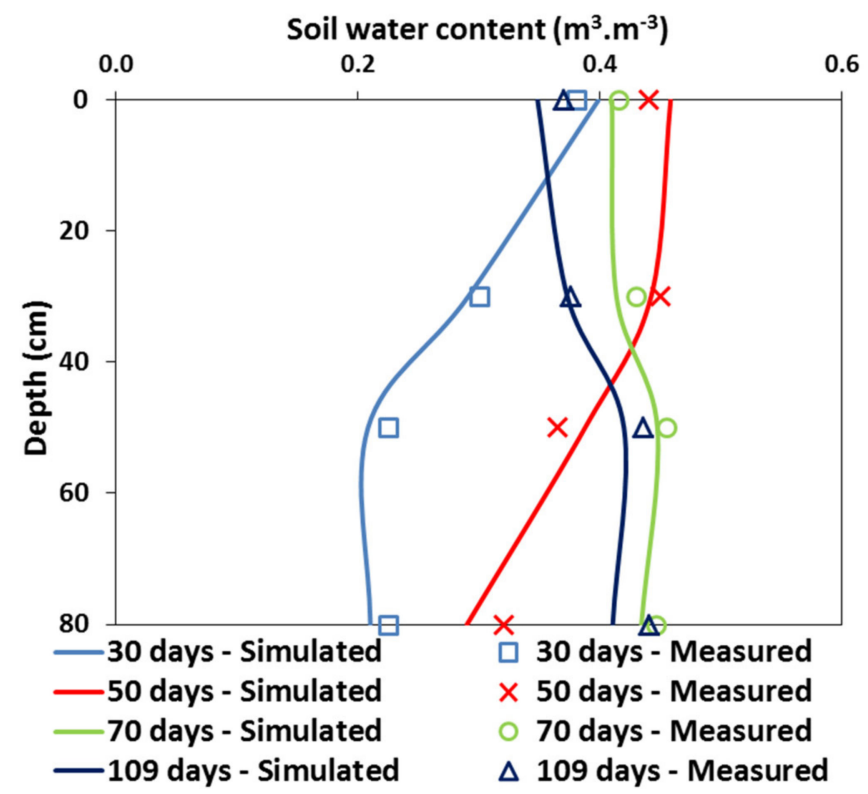

Figure 4. Measured and simulated soil water content profiles for the treatment with the irrigation water quality of $0 \mathrm{dS} \cdot \mathrm{m}^{-1}$ at 30,50, 70, and 109 days.

The calibrated parameters were then used in model validation simulations. The measured and simulated soil water content profiles for the treatments with saline water of $3.5 \mathrm{dS} \cdot \mathrm{m}^{-1}$ and $7 \mathrm{dS} \cdot \mathrm{m}^{-1}$ are depicted in Figures 5 and 6, respectively.

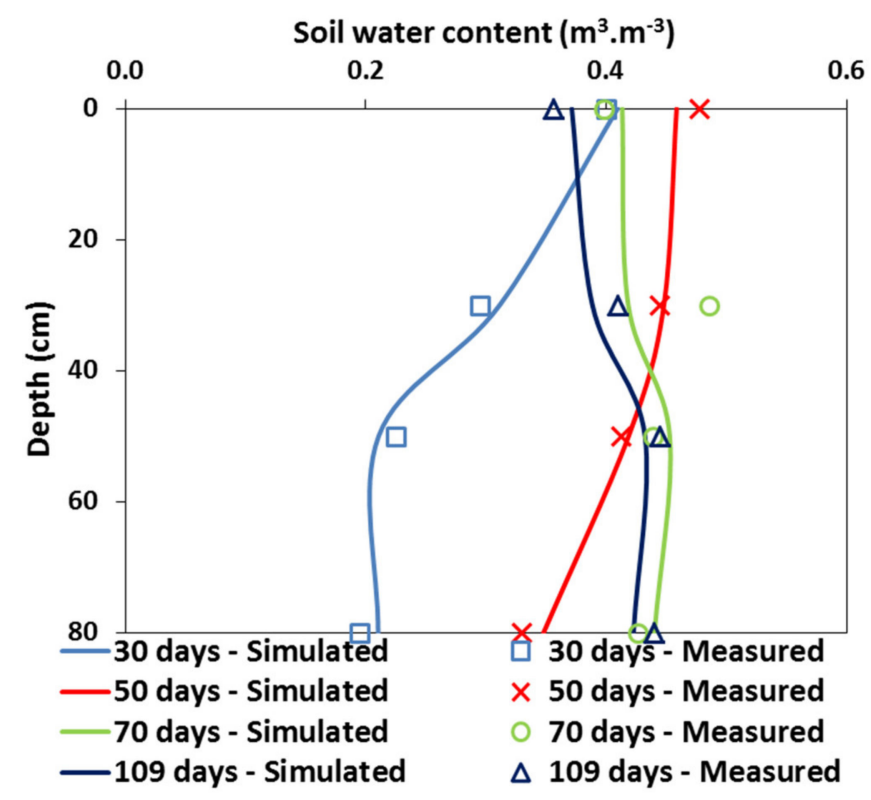

Figure 5. Measured and simulated soil water content profiles for the treatment with the irrigation water quality of $3.5 \mathrm{dS} \cdot \mathrm{m}^{-1}$ at $30,50,70$, and 109 days. 


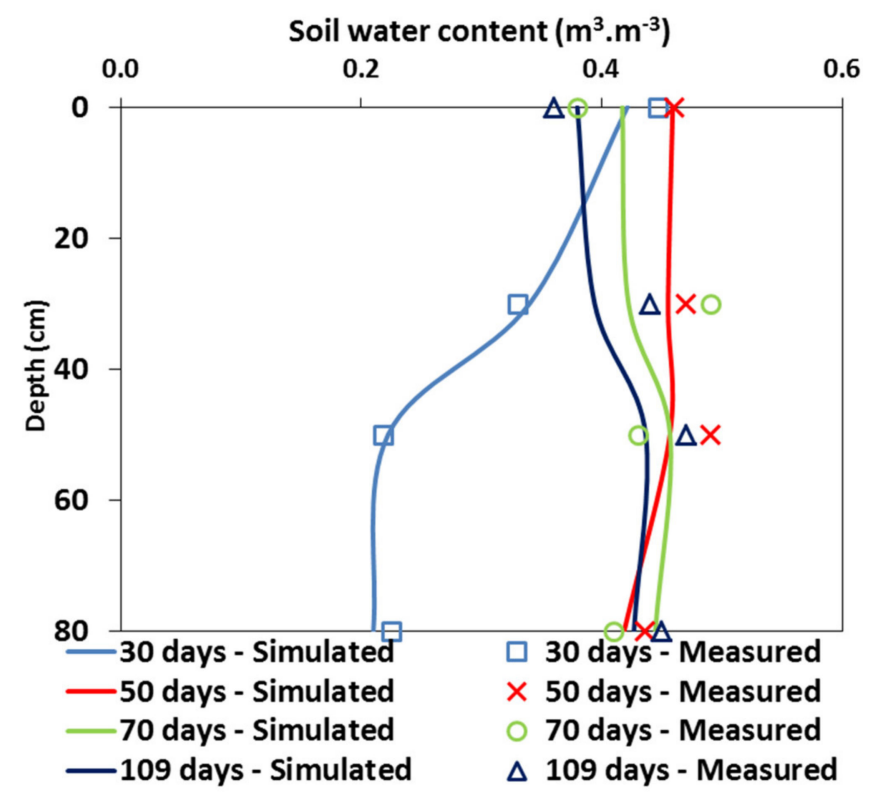

Figure 6. Measured and simulated soil water content profiles for the treatment with the irrigation water quality of $7 \mathrm{dS} \cdot \mathrm{m}^{-1}$ at $30,50,70$, and 109 days.

Graphically, the simulated values of soil water contents are close to those measured at each sampling depth and each sampling date in both validation experiments. Slight deviations from the measured values were observed in the layers between 20 and $40 \mathrm{~cm}$ on days 70 and 109 . These graphical results are confirmed by the RMSE, CD,EF, and CRM values calculated for each profile (Table 4) with statistical indicators having less than optimal values on days 70 and 109, confirming model deviations from measured values.

Table 4. The statistical indicators for measured and simulated soil water content profiles at different sampling dates for treatments irrigated with saline waters.

\begin{tabular}{|c|c|c|c|c|c|}
\hline & Water Quality & 30 Days & 50 Days & 70 Days & 109 Days \\
\hline \multirow{3}{*}{ RMSE (\%) } & $0 \mathrm{dS} \cdot \mathrm{m}^{-1}$ & 5.40 & 5.30 & 2.60 & 4.90 \\
\hline & $3.5 \mathrm{dS} \cdot \mathrm{m}^{-1}$ & 5.00 & 3.30 & 8.10 & 7.00 \\
\hline & $7 \mathrm{dS} \cdot \mathrm{m}^{-1}$ & 5.10 & 4.30 & 10.40 & 7.50 \\
\hline \multirow{3}{*}{$C D$} & $0 \mathrm{dS} \cdot \mathrm{m}^{-1}$ & 0.68 & 0.67 & 0.68 & 0.95 \\
\hline & $3.5 \mathrm{dS} \cdot \mathrm{m}^{-1}$ & 0.91 & 1.62 & 3.33 & 2.60 \\
\hline & $7 \mathrm{dS} \cdot \mathrm{m}^{-1}$ & 1.13 & 0.69 & 5.03 & 1.81 \\
\hline \multirow{3}{*}{$E F$} & $0 \mathrm{dS} \cdot \mathrm{m}^{-1}$ & 0.95 & 0.85 & 0.5 & 0.65 \\
\hline & $3.5 \mathrm{dS} \cdot \mathrm{m}^{-1}$ & 0.96 & 0.93 & -0.28 & 0.77 \\
\hline & $7 \mathrm{dS} \cdot \mathrm{m}^{-1}$ & 0.97 & -0.07 & -0.21 & 0.4 \\
\hline \multirow{3}{*}{ CRM } & $0 \mathrm{dS} \cdot \mathrm{m}^{-1}$ & 0.02 & 0.01 & 0.02 & 0.04 \\
\hline & $3.5 \mathrm{dS} \cdot \mathrm{m}^{-1}$ & -0.02 & 0.01 & 0.01 & 0.02 \\
\hline & $7 \mathrm{dS} \cdot \mathrm{m}^{-1}$ & 0.02 & 0.04 & -0.02 & 0.05 \\
\hline
\end{tabular}

The simulated cumulative bottom flux, calculated by Hydrus-1D, was $24 \mathrm{~cm}$ for the scenario irrigated with $\mathrm{FW}, 31 \mathrm{~cm}$ for the scenario irrigated with the $3.5 \mathrm{dS} \cdot \mathrm{m}^{-1}$ water, and $38 \mathrm{~cm}$ for the scenario irrigated with the $7 \mathrm{dS} \cdot \mathrm{m}^{-1}$ water. The leached amounts of water increased because of reduced root water uptake due to the effects of the saline water used for irrigation.

\subsubsection{Soil Salts Profiles}

The salinity profiles measured during the tomato crop experiment with the irrigation water quality of $0 \mathrm{dS} \cdot \mathrm{m}^{-1}$ are plotted together with simulated values of soil salts contents in Figure 7. Overall, 
a good fitting is observed between measured and simulated (using calibrated parameters) values of soil salts contents at the four sampling dates. The soil electrical conductivity is generally slightly overestimated by the model, with RMSE values (for all depths per date) of 1.6, 4.3, 5.1, and 9.6\%, respectively. The $C D, E F$, and $C R M$ values indicate that Hydrus-1D was able to reproduce the salts dynamic in the soil satisfactorily.

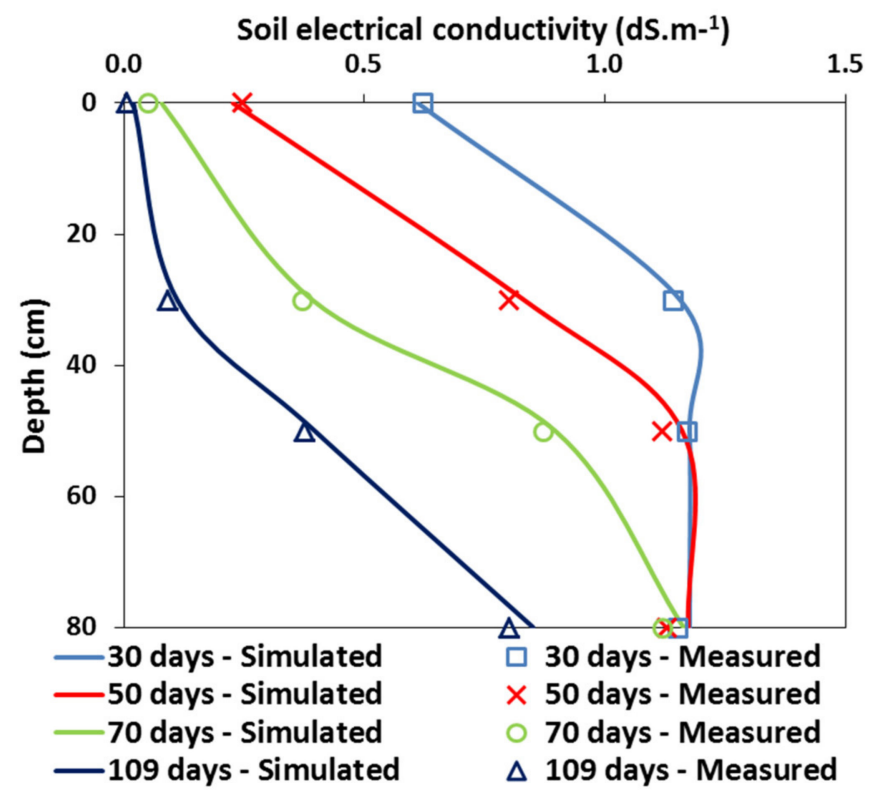

Figure 7. Measured and simulated soil salts profiles for the treatment with the irrigation water quality of $0 \mathrm{dS} \cdot \mathrm{m}^{-1}$ at $30,50,70$, and 109 days.

The validation results for the salts profiles for the two treatments with saline waters are given in Figures 8 and 9. The measured and simulated salts content profiles are similar at each sampling depth and each sampling date. The graphical results are confirmed by the statistical indicators (Table 5).

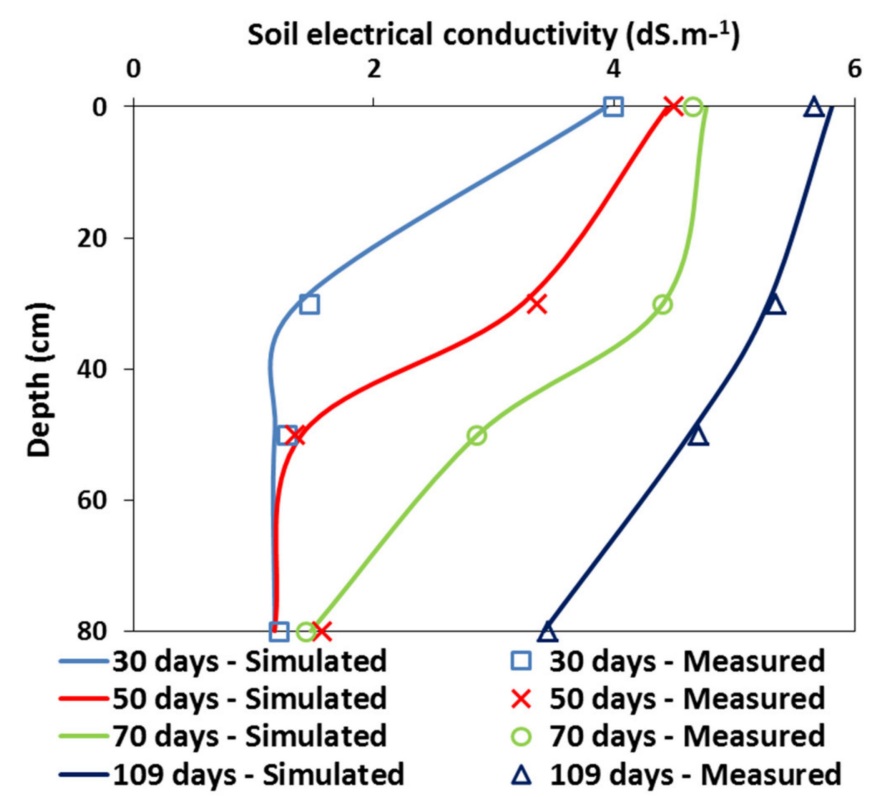

Figure 8. Measured and simulated soil salts profiles for the experiment with the irrigation water quality of $3.5 \mathrm{dS} \cdot \mathrm{m}^{-1}$ at $30,50,70$, and 109 days. 


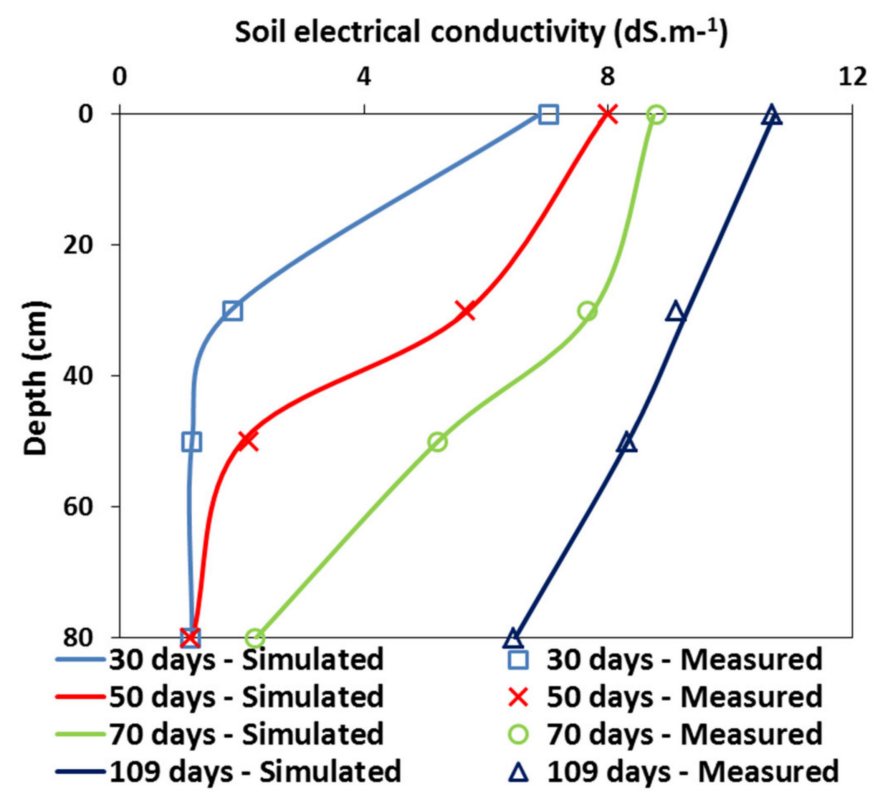

Figure 9. Measured and simulated soil salts profiles for the experiment with the irrigation water quality of $7 \mathrm{dS} \cdot \mathrm{m}^{-1}$ at $30,50,70$, and 109 days.

Table 5. The statistical indicators for measured and simulated soil salts profiles at different sampling dates for treatments irrigated with saline waters.

\begin{tabular}{|c|c|c|c|c|c|}
\hline & Water Quality & 30 Days & 50 Days & 70 Days & 109 Days \\
\hline \multirow{3}{*}{ RMSE (\%) } & $0 \mathrm{dS} \cdot \mathrm{m}^{-1}$ & 5.40 & 5.30 & 2.60 & 4.90 \\
\hline & $3.5 \mathrm{dS} \cdot \mathrm{m}^{-1}$ & 5.00 & 3.30 & 8.10 & 7.00 \\
\hline & $7 \mathrm{dS} \cdot \mathrm{m}^{-1}$ & 5.10 & 4.30 & 10.40 & 7.50 \\
\hline \multirow{3}{*}{$C D$} & $0 \mathrm{dS} \cdot \mathrm{m}^{-1}$ & 0.91 & 0.87 & 0.97 & 0.91 \\
\hline & $3.5 \mathrm{dS} \cdot \mathrm{m}^{-1}$ & 0.98 & 0.92 & 0.98 & 0.90 \\
\hline & $7 \mathrm{dS} \cdot \mathrm{m}^{-1}$ & 1.05 & 1.00 & 1.00 & 0.97 \\
\hline \multirow{3}{*}{$E F$} & $0 \mathrm{dS} \cdot \mathrm{m}^{-1}$ & 0.99 & 0.99 & 0.99 & 0.99 \\
\hline & $3.5 \mathrm{dS} \cdot \mathrm{m}^{-1}$ & 0.99 & 0.97 & 0.99 & 0.98 \\
\hline & $7 \mathrm{dS} \cdot \mathrm{m}^{-1}$ & 0.99 & 0.99 & 0.99 & 0.99 \\
\hline \multirow{3}{*}{$C R M$} & $0 \mathrm{dS} \cdot \mathrm{m}^{-1}$ & -0.01 & -0.03 & -0.05 & -0.09 \\
\hline & $3.5 \mathrm{dS} \cdot \mathrm{m}^{-1}$ & 0.04 & 0.05 & -0.01 & 0.01 \\
\hline & $7 \mathrm{dS} \cdot \mathrm{m}^{-1}$ & 0.01 & 0.01 & 0.01 & -0.01 \\
\hline
\end{tabular}

\subsubsection{Crop Yields}

The relative crop yield $\left(Y_{r}\right)$ cannot be estimated directly by the Hydrus-1D model. According to [8], the relative crop yield $\left(Y_{r}\right)$ can be estimated as the ratio between the actual and potential (or maximum) root water uptake (transpiration), and these two values are available in the model. Figure 10 displays measured and simulated relative crop yields as a function of the irrigation water quality $\left(E C_{w}\right)$. According to [27], $Y_{r}=Y_{a} Y_{\max }$, where $Y_{a}$ is the measured yield, and $Y_{\max }$ is the maximum yield. In our case, $Y_{\max }$ corresponds to the weight obtained in the experiment with freshwater irrigation and is equal to $2.53 \mathrm{~kg} /$ plant.

As shown in Figure 10, the relative yield was reduced as the salinity of the irrigation water increases. The model was able to reproduce the observed decrease in relative yield, although not to the same extent as observed. Measured relative yields, $Y_{r}$, were reduced only slightly when irrigation water with $E C_{w}=3.5 \mathrm{dS} \cdot \mathrm{m}^{-1}$ was used and nearly by half with $E C_{w}=7 \mathrm{dS} \cdot \mathrm{m}^{-1}$. In contrast, simulated yields were overestimated by the model in both treatments irrigated with saline waters. The observed effects of the salinity stress were larger than those simulated. The parameters (either the threshold 
or the slope) of the salinity stress response function would have to be adjusted to obtain a better correspondence between simulated and measured relative yields. Note that the model predicted, due to the saturation stress, a slight reduction in relative yield even for the experiment irrigated with fresh water.

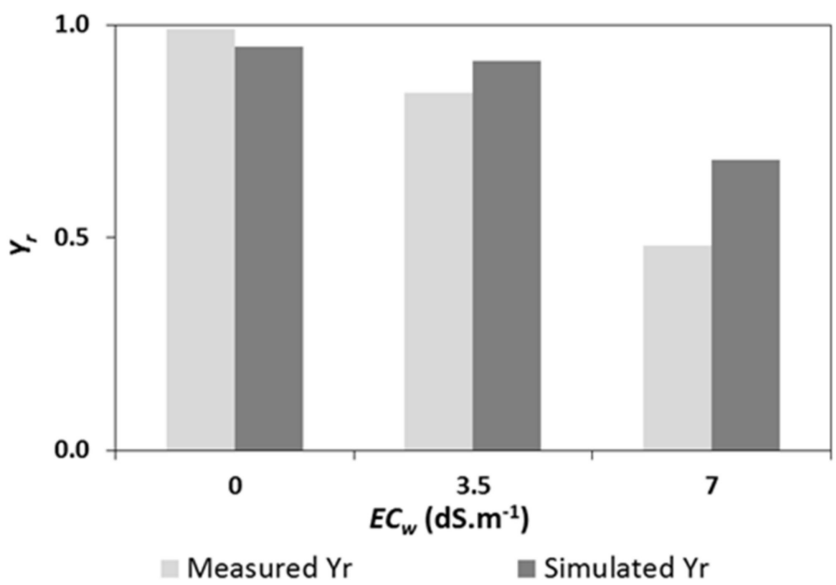

Figure 10. The measured and simulated tomato relative yields $\left(Y_{r}\right)$ as a function of irrigation water electrical conductivity $\left(E C_{w}\right)$.

\subsection{Evaluation of the Irrigation Method}

The success of the calibrated and validated Hydrus-1D model in simulating water and salt dynamics for experiments with the tomato crop under field conditions, also motivated employing the model for evaluating alternative irrigation management strategies.

Figure 11 depicts relative yield, $Y_{r}$, simulated using Hydrus-1D with the S-shape model for scenarios with three irrigation water qualities when $50 \%$ less irrigation water was used. Since the tomato yields decreased only slightly when freshwater was used, the irrigation doses calculated by the CROPWAT software must be grossly overestimated [28,29]. The results of Figure 12 show a substantial reduction in the relative yield when the high salinity water was used for irrigation. These results are in agreement with those of Saad et al. [30], who observed a reduction in tomato fruit yield of $40 \%$ using irrigation of $50 \%$ of $E T_{c}$ and water of $9 \mathrm{dS} \cdot \mathrm{m}^{-1}$.

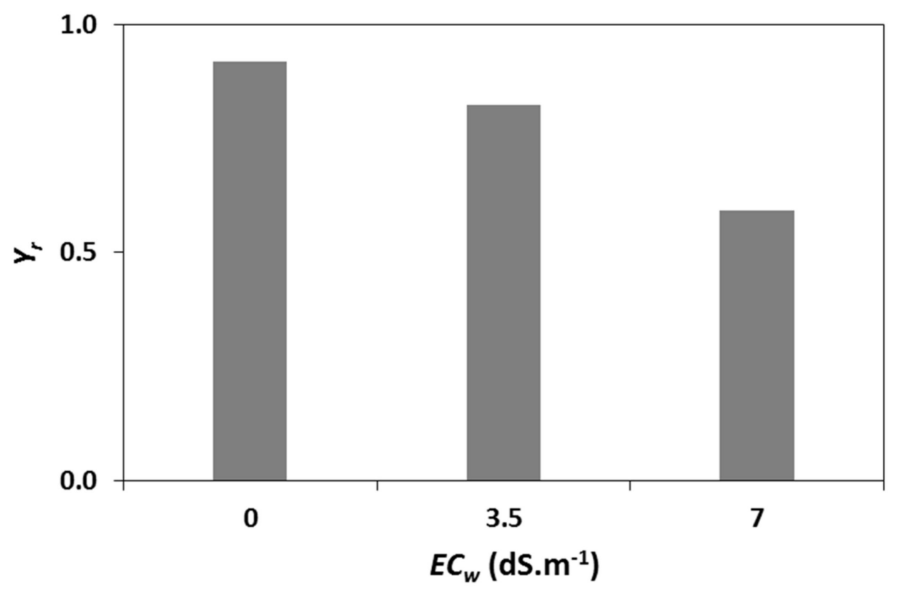

Figure 11. The simulated relative yields $\left(Y_{r}\right)$ of tomato for scenarios with different electrical conductivities of irrigation water $\left(E C_{w}\right)$ and with a $50 \%$ irrigation reduction. 


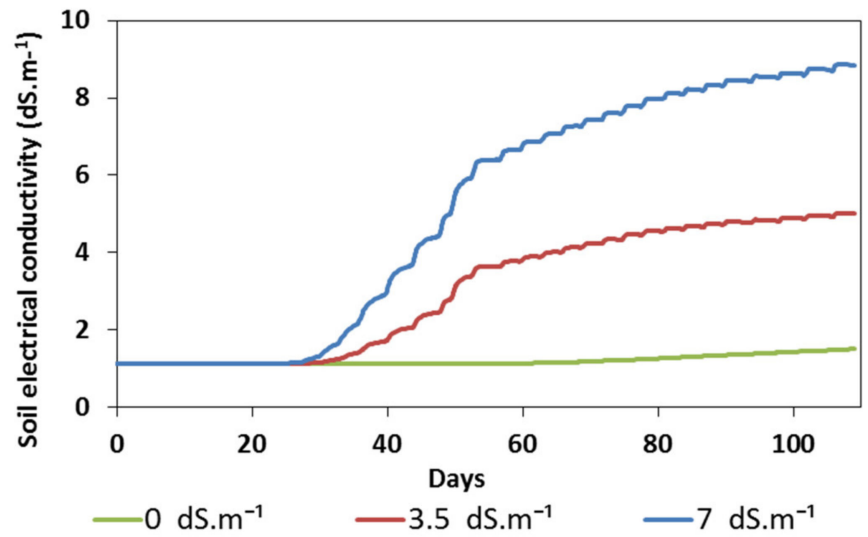

Figure 12. Simulated rootzone soil salinity for scenarios with different water qualities and a $50 \%$ reduction in irrigation water.

Figure 12 shows the simulated root zone soil salinity $\left(E C_{\mathrm{e}}\right)$ as it increases over the season with the salinity of the irrigation water. $E C_{e}$ exceeds $8 \mathrm{dS} \cdot \mathrm{m}^{-1}$ after three months of irrigation with the most saline water $\left(E C_{w}=7 \mathrm{dS} \cdot \mathrm{m}^{-1}\right)$, which increases the risk of soil salinization. On the other hand, soil salinity in the root zone remains under $4.5 \mathrm{dS} \cdot \mathrm{m}^{-1}$ when moderately saline water is used $\left(E C_{w}=3.5 \mathrm{dS} \cdot \mathrm{m}^{-1}\right)$. Such root zone salinity can be tolerable to tomato crops, reducing relative yield by only about $15 \%$.

\section{Discussion}

One of the major weaknesses of numerical models is the lack of calibration and validation in field conditions [31]. In this study, a field experiment involving water and solute dynamics with root water uptake allowed for the successful calibration and validation of the Hydrus-1D model. The RMSEs for measured and simulated values of water contents and salt concentrations were low and showed the ability of the model to reproduce water and salt profiles, and subsequently to evaluate the effects of irrigation with brackish waters on the soil and tomato crop [32-34]. Irrigation with saline water with $E C_{w}=3.5 \mathrm{dS} \cdot \mathrm{m}^{-1}$ can be tolerable to the crop and induces a low soil salinization risk. However, saline water with $E C_{w}=7 \mathrm{dS} \cdot \mathrm{m}^{-1}$ reduces $Y_{r}$ nearly by half and increases the soil salinity in the short-term [35] and could be disastrous for the crop after several irrigation cycles [36]. This risk is aggravated when the leaching fraction is reduced in the case of a deficit irrigation strategy [31]. The use of a drip irrigation system associated with proper management practices such as increasing irrigation frequency [37] or controlled deficit irrigation [38], can mitigate these effects on both soil and crops. Replication of this experiment over at least three years can provide a strong statistical significance of the effects of brackish water on tomato crop yields.

The used modeling approach was based on the simulation of the overall salinity. An alternative geochemical approach that considers the multicomponent solute reactions and transport (as implemented in the Unsatchem module of HYDRUS-1D [12]) for the calculation of soil electrical conductivity may be more appropriate for optimizing the management of irrigation with highly saline waters [11,39].

\section{Conclusions}

In arid and semi-arid regions like Tunisia, the scarcity of water resources of good quality has led to the use of brackish water in agriculture. Salts accumulated in the soil due to irrigation with these waters have negative consequences for both soil and crop yields. Experiments carried out on a tomato crop irrigated with three water qualities $\left(0 \mathrm{dS} \cdot \mathrm{m}^{-1}, 3.5 \mathrm{dS} \cdot \mathrm{m}^{-1}\right.$, and $\left.7 \mathrm{dS} \cdot \mathrm{m}^{-1}\right)$ allowed the study the variations of water and salt dynamics in the soil. Observed soil salt profiles indicated progressive soil salinization when the plot was irrigated with water of $7 \mathrm{dS} \cdot \mathrm{m}^{-1}$, with soil salinity reaching a value of $8 \mathrm{dS} \cdot \mathrm{m}^{-1}$ at the soil surface. The effects of irrigation with saline waters on the tomato crop 
were studied using a modeling approach with Hydrus-1D. The study of the scenario where the crop water requirements were reduced by half showed that, in all three experiments, the crop yields were not significantly affected. The irrigation amounts of tomato crop estimated by CROPWAT 8.0 were overestimated. This overestimation could have been caused by the use of crop coefficients not adapted to tomato under the local conditions of the current study.

Author Contributions: Conceptualization, S.K. and B.B.N.; data curation, S.K., R.I., and H.B.; formal analysis, S.K., J.Š., and S.B.M.; funding acquisition, R.I., B.B.N., and M.A.B.A.; investigation, S.K., I.D., and M.R.; methodology, S.K., R.I., and M.R.; project administration, S.K., M.R., and B.B.N.; resources, S.K., H.B., and M.A.B.A.; software, S.K., S.B.M., and B.B.N.; supervision, B.B.N.; validation, I.D., A.Y., M.R., H.B., and M.A.B.A.; visualization, I.D., J.Š., A.Y., R.I., S.B.M., M.R., H.B,. and M.A.B.A.; writing—original draft, S.K. and J.Š.; writing-review and editing, I.D., J.S., and A.Y. All authors have read and agreed to the published version of the manuscript.

Funding: This research received no external funding.

Acknowledgments: The authors would like to appreciate the valuable comments by anonymous reviewers, which helped to improve the manuscript.

Conflicts of Interest: The authors declare no conflict of interest.

\section{References}

1. Jahin, H.S.; Abuzaid, A.S.; Abdellatif, A.D. Using multivariate analysis to develop irrigation water quality index for surface water in Kafr El-Sheikh Governorate, Egypt. Environ. Technol. Innov. 2020, 17, 100532. [CrossRef]

2. Bueno, M.; Lendínez, M.L.; Calero, J.; Cordovilla, M.D.P. Salinity responses of three halophytes from inland saltmarshes of Jaén (southern Spain). Flora 2020, 266, 151589. [CrossRef]

3. Hussain, M.I.; Muscolo, A.; Farooq, M.; Ahmad, W. Sustainable use and management of non-conventional water resources for rehabilitation of marginal lands in arid and semiarid environments. Agric. Water Manag. 2019, 221, 462-476. [CrossRef]

4. Liu, B.; Wang, S.; Kong, X.; Liu, X.; Sun, H. Modeling and assessing feasibility of long-term brackish water irrigation in vertically homogeneous and heterogeneous cultivated lowland in the North China Plain. Agric. Water Manag. 2019, 211, 98-110. [CrossRef]

5. Pedrero, F.; Kalavrouziotis, I.; Cabañero, J.J.A.; Koukoulakis, P.; Asano, T. Use of treated municipal wastewater in irrigated agriculture-Review of some practices in Spain and Greece. Agric. Water Manag. 2010, 97, 1233-1241. [CrossRef]

6. Ayers, R.S.; Westcot, D.W. Water Quality for Agriculture; Irrigation and Drainage, No. 29; FAO: Rome, Italy, 1985.

7. Golshan, M.; Colombani, N.; Mastrocicco, M. Assessing Aquifer Salinization with Multiple Techniques along the Southern Caspian Sea Shore (Iran). Water 2018, 10, 348. [CrossRef]

8. Kanzari, S.; Ben Nouna, B.; Ben Mariem, S.; Rezig, M. Hydrus-1D model calibration and validation in various field conditions for simulating water flow and salts transport in a semi-arid region of Tunisia. Sustain. Environ. Res. 2018, 28, 350-356. [CrossRef]

9. Azad, N.; Behmanesh, J.; Rezaverdinejad, V.; Abbasi, F.; Navabian, M. Developing an optimization model in drip fertigation management to consider environmental issues and supply plant requirements. Agric. Water Manag. 2018, 208, 344-356. [CrossRef]

10. Yang, H.; Du, T.; Mao, X.; Ding, R.; Shukla, M.K. A comprehensive method of evaluating the impact of drought and salt stress on tomato growth and fruit quality based on EPIC growth model. Agric. Water Manag. 2019, 213, 116-127. [CrossRef]

11. Phogat, V.; Mallants, D.; Cox, J.; Šimůnek, J.; Oliver, D.; Awad, J. Management of soil salinity associated with irrigation of protected crops. Agric. Water Manag. 2020, 227, 105845. [CrossRef]

12. Šimůnek, J.; Genuchten, M.T.; Šejna, M. Recent Developments and Applications of the HYDRUS Computer Software Packages. Vadose Zone J. 2016, 15, 25. [CrossRef]

13. Oster, J.; Letey, J.; Vaughan, P.; Wu, L.; Qadir, M. Comparison of transient state models that include salinity and matric stress effects on plant yield. Agric. Water Manag. 2012, 103, 167-175. [CrossRef] 
14. He, K.; Yang, Y.; Yang, Y.; Chen, S.; Hu, Q.; Liu, X.; Gao, F. HYDRUS Simulation of Sustainable Brackish Water Irrigation in a Winter Wheat-Summer Maize Rotation System in the North China Plain. Water 2017, 9, 536. [CrossRef]

15. Li, H.; Yi, J.; Zhang, J.; Zhao, Y.; Si, B.; Hill, R.; Cui, L.; Liu, X. Modeling of Soil Water and Salt Dynamics and Its Effects on Root Water Uptake in Heihe Arid Wetland, Gansu, China. Water 2015, 7, 2382-2401. [CrossRef]

16. Allen, R.G.; Pereira, L.S.; Raes, D.; Smith, M. Crop Evapotranspiration-Guidelines for Computing Crop Water Requirements; FAO Irrigation and Drainage Paper 56; FAO: Rome, Italy, 1998.

17. Smith, M. CROPWAT: A Computer Program for Irrigation Planning and Management; No. 46; FAO: Rome, Italy, 1992; p. 126.

18. Richards, L.A.; Fireman, M. Pressure-plate apparatus for measuring moisture sorption and transmission by soils. Soil Sci. 1943, 56, 395-404. [CrossRef]

19. Genuchten, M.T. A Closed-form Equation for Predicting the Hydraulic Conductivity of Unsaturated Soils. Soil Sci. Soc. Am. J. 1980, 44, 892-898. [CrossRef]

20. Van Genuchten, M.T.; Leij, F.T.; Yates, S.R. The RETC Code for Quantifying the Hydraulic Functions of Unsaturated Soils; U.S. Environmental Protection Agency, Robert S. Kerr Environmental Research Laboratory: Ada, OK, USA, 1991.

21. Kanzari, S.; Bouhlila, R. Laboratory method for estimating solute transport parameters of an unsaturated soil. Am. J. Geochem. Geophys. 2015, 1, 151-156.

22. Kanzari, S.; Sahraoui, H. Laboratory method for characterization of soil/water adsorption coefficient. Exper. J. 2014, 29, 1952-1956.

23. Madre, J.F. Logiciel Mesurim Pro v3.4. Available online: www.dosadi.com.2013 (accessed on 29 May 2020).

24. Van Genuchten, M.T. A Numerical Model for Water and Solute Movement in and Below the Root Zone; Research Report No. 121; U.S. Salinity Laboratory, USDA, ARS: Riverside, CA, USA, 1987.

25. Van Straten, G.; De Vos, A.; Rozema, J.; Bruning, B.; Van Bodegom, P. An improved methodology to evaluate crop salt tolerance from field trials. Agric. Water Manag. 2019, 213, 375-387. [CrossRef]

26. Loague, K.; Green, R.E. Statistical and graphical methods for evaluating solute transport models: Overview and application. J. Contam. Hydrol. 1991, 7, 51-73. [CrossRef]

27. Steduto, P.; Hsiao, T.C.; Fereres, E.; Raes, D. Crop Yield Response to Water; FAO Irrigation and Drainage Paper No. 66; FAO: Rome, Italy, 2012; p. 505.

28. Etissa, E.; Dechassa, N.; Alemayehu, Y. Estimation of Yield Response (Ky) and Validation of CropWat for Tomato under Different Irrigation Regimes. Irrig. Drain. Syst. Eng. 2016, 5, 167. [CrossRef]

29. Kifle, T. Evaluation of tomato response to deficit irrigation at Humbo Woreda, Ethiopia. J. Nat. Sc. Res. 2018, 6, 57-68.

30. Saad, A.F.; Shalaby, A.A.; Mokhtar, A.M. Influence of Deficit Irrigation Using Saline Water on Yield of Tomato under Two Irrigation Systems. Alex. Sci. Exch. J. 2018, 39, 35-47. [CrossRef]

31. Bastiaanssen, W.; Allen, R.; Droogers, P.; D’Urso, G.; Steduto, P. Twenty-five years modeling irrigated and drained soils: State of the art. Agric. Water Manag. 2007, 92, 111-125. [CrossRef]

32. Gawad, G.A.; Arslan, A.; Gaihbe, A.; Kadouri, F. The effects of saline irrigation water management and salt tolerant tomato varieties on sustainable production of tomato in Syria (1999-2002). Agric. Water Manag. 2005, 78, 39-53. [CrossRef]

33. Malash, N.; Flowers, T.; Ragab, R. Effect of irrigation systems and water management practices using saline and non-saline water on tomato production. Agric. Water Manag. 2005, 78, 25-38. [CrossRef]

34. Reca, J.; Trillo, C.; Sánchez, J.; Martínez, J.; Valera, D. Optimization model for on-farm irrigation management of Mediterranean greenhouse crops using desalinated and saline water from different sources. Agric. Syst. 2018, 166, 173-183. [CrossRef]

35. Du, Y.-D.; Cao, H.-X.; Liu, S.-Q.; Gu, X.; Cao, Y.-X. Response of yield, quality, water and nitrogen use efficiency of tomato to different levels of water and nitrogen under drip irrigation in Northwestern China. J. Integr. Agric. 2017, 16, 1153-1161. [CrossRef]

36. Minhas, P.; Ramos, T.B.; Ben-Gal, A.; Pereira, L.S. Coping with salinity in irrigated agriculture: Crop evapotranspiration and water management issues. Agric. Water Manag. 2020, 227, 105832. [CrossRef]

37. Liu, H.; Duan, A.-W.; Li, F.; Sun, J.-S.; Wang, Y.-C.; Sun, C.-T. Drip Irrigation Scheduling for Tomato Grown in Solar Greenhouse Based on Pan Evaporation in North China Plain. J. Integr. Agric. 2013, 12, 520-531. [CrossRef] 
38. Valcárcel, M.; Lahoz, I.; Campillo, C.; Martí, R.; Leiva-Brondo, M.; Roselló, S.; Cebolla, J. Controlled deficit irrigation as a water-saving strategy for processing tomato. Sci. Hortic. 2020, 261, 108972. [CrossRef]

39. Phogat, V.; Mallants, D.; Cox, J.W.; Šimůnek, J.; Oliver, D.P.; Pitt, T.; Petrie, P.R. Impact of long-term recycled water irrigation on crop yield and soil chemical properties. Agric. Water Manag. 2020, 237, 106167. [CrossRef]

(C) 2020 by the authors. Licensee MDPI, Basel, Switzerland. This article is an open access article distributed under the terms and conditions of the Creative Commons Attribution (CC BY) license (http://creativecommons.org/licenses/by/4.0/). 